\title{
Feasibility of using Metakaolin as a Self-Compacted Concrete Constituent Material
}

\author{
[Ibrahim, H.M. ${ }^{(1)}$, Arab, M.A. ${ }^{(2)}$ and Faisal, A.M. ${ }^{(3)}$ ]
}

\begin{abstract}
By minimizing the Portland cement (PC) content in concrete using supplementary cementitious material, reducing the $\mathrm{CO}_{2}$ emission to the atmosphere is occurred. Metakaolin is one of these environmentally friendly materials. One of the most promising types of concrete is Self-compacted concrete (SCC). This research intends to investigate and assess the fresh and hardened properties of SCC containing Metakaolin by studying the impact of utilizing different cement and Metakaolin contents on concrete flow-ability, passingability and compressive and tensile strength. Fresh properties were investigated using new developed test named MSF Apparatus test and compared with the standard tests slump flow test and J-Ring test. The new developed test was highly accurate in SCC indication. Results showed adequate improvements by increasing Metakaolin content and cement content on the compressive and tensile strength. $15 \%$ Metakaolin content by the weight of cement as adding or replacement gives the best results.
\end{abstract}

Keywords - self-compacted, high strength, Metakaolin, environmental, flow-ability, fresh concrete, hardened concrete.

\section{Introduction}

Concrete has been developing in many ways to enhance the quality and properties of concrete. Self-compacting concrete (SCC) is one of the keys for the realization of durable concrete structures independent of the quality of construction work (Christianto H., 2004).

The manufacturing of High Strength Self Compacted Concrete that permanently meets requirements for workability and strength development places stricter requirements on the choice of materials than concrete of lower strength (Rashid et al., 2009). Numerous special ingredients are required in the production of high strength self-compacted concrete such as high-range water reducer (HRWR), supplementary cementing material (SCM), besides the basic materials used for ordinary (Sanjay et al., 2013).

Prof. Hassan Mohammed Hassan Ibrahim ${ }^{(1)}$

Faculty of Engineering / Port Said University Egypt

Dr. Mohammed Abd El_Salam Arab ${ }^{(2)}$

Faculty of Engineering / Beni Suef University

Egypt

Eng. Ahmed Mahmoud Salman Faisal ${ }^{(3)}$ Faculty of Engineering / Sinai University Egypt
SCMs can be used for improving concrete performance in its fresh and hardened state. They are primarily used for improved workability, durability and strength. These materials could be produced as a by products from other processes or from natural materials such as Metakaolin (NRMCA, 2000).

Metakaolin, is a comparatively new material used in the concrete industry becomes one of the plenty ingredients in the production of an economical and environmentally friendly concrete of more than $40 \mathrm{MPa}$. It is traditionally using Silica Fume to produce High Strength Concrete but when it is replaced by Metakaolin, the concrete properties and several features like strength, durability, water permeability, workability and flow-ability are improved (Shekarchi et al., 2010). The presence of MK has an immense effect on the hydration of Portland cement (PC). When Portland cement alone hydrates, typically $20-30 \%$ of the resulting paste mass is $\mathrm{CH}$. However, when $\mathrm{MK}$ is introduced, it reacts rapidly with these newly forming $\mathrm{CH}$ compounds to produce supplementary calcium silicate hydrate (C-S-H) (Yusuff, 2005). Metakaolin substantially decreases the permeability of concrete, where the pores size in cement paste are reduced and many finer particles are transformed into discrete pores. Metakaolin improves compressive and flexural strengths. Also it leads to better shrinkage and crack control by reducing heat of hydration (Shekarchi et al., 2010). The utilization of this material is also environmentally friendly since it helps in reducing the $\mathrm{CO} 2$ emission to the atmosphere by the minimization of the Portland cement (PC) consumption (Rawat, 2012).

\section{Research Significance}

The present work will focus on developing selfcompacted concrete mixtures using locally available materials. This experimental program was performed in two main phases to investigate the impact of using different cement and Metakaolin contents on the mechanical properties of self-compacting concrete samples and trying to achieve to High Strength Self-compacted concrete. The procedure of this research is divided into two main phases as follow:

\section{A. The First Phase}

This phase aims to determine the optimum water to binder ratios for different cement and Metakaolin contents to achieve the requirements of self-compacted concrete. Fresh concrete with different water to binder ratio was tested by using new developed test. MSF apparatus shown in Fig. 4 is the chosen name for the new test procedure.

\section{B. The Second Phase}

The second phase was based on testing 39 different mixtures from M1 to M39 which determined with the optimum water to binder ratios from the first stage. Fresh 
Proc. of the Fourth International Conference on Advances in Civil, Structural and Environmental Engineering - ACSEE 2016. Copyright (C) Institute of Research Engineers and Doctors. All rights reserved.

ISBN: 978-1-63248-114-6 doi: 10.15224/ 978-1-63248-114-6-25

and hardened concrete properties were investigated in this phase. Slum flow test and J-ring test were carried out for all mixes to calibrate the determined water to binder ratios from the first phase. The Compressive strength and indirect tension tests were performed to investigate the properties of hardened self-compacted concrete of the chosen mixes

\section{The Second Phase}

The second phase was based on testing 39 different mixtures from M1 to M39 which determined with the optimum water to binder ratios from the first phase. Fresh and hardened concrete properties were investigated in this phase. Slum flow test and J-ring test were carried out for all mixes to calibrate the determined water to binder ratios from the first phase. The Compressive strength and indirect tension tests were performed to investigate the properties of hardened self-compacted concrete of the chosen mixes.

\section{Materials and Experimental Program}

\section{A. Materials}

1) Cement: The used cement was ordinary Portland cement CEM I N52.5. Its chemical and physical characteristics satisfy the Egyptian Standard Specification (E.S.S. 4756-1/2009).

2) Fine aggregate: Natural and clean sand with a specific gravity $2.71 \mathrm{t} / \mathrm{m}^{3}$ was used.

3) Coarse aggregate: Crushed Dolomite is used as coarse aggregate. The specific gravity and water absorption of the coarse aggregate are $2.65 \mathrm{t} / \mathrm{m} 3$ and $0.6 \%$ respectively. The grain size distribution curve for used aggregate is shown in Fig. 1.

4) Super-plasticizer: Sika Viscocrete 3425 a third generation polycarboxylate based super-plasticizer supplied by Sika Egypt company is the used super-plasticizer which meets the requirements of super-plasticizer according to ASTM-C-494, types G and F (ASTM C494, 2003). The used super-plasticizer has $1.08 \mathrm{Kg} /$ lit density, $4.0 \mathrm{pH}$ value and $40 \%$ solid content (by weight).

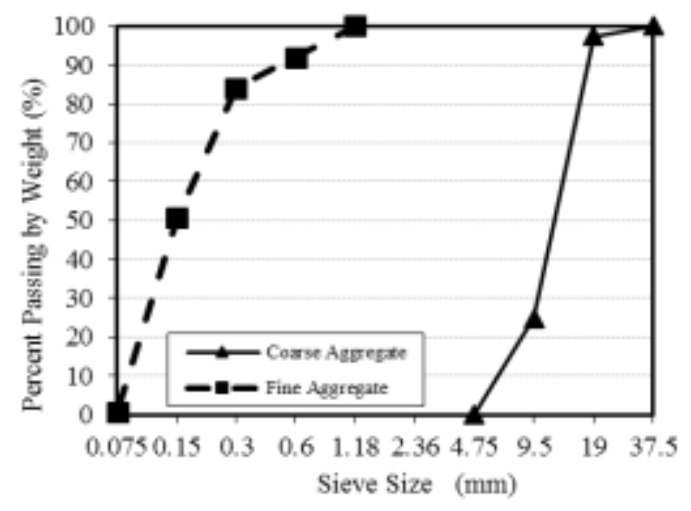

Figure 1. The Grain Size Distribution Curve for Used Aggregate

5) Metakaolin (MK): Metakaolin sample is shown in Fig. 2. The used MK was produced by Nourmetec for building and Refractories Company. The microstructural composition of the used Metakaolin was investigated by means of powder X-ray diffraction analysis (XRD) Fig. 3. The chemical components analysis was shown in Table 1.
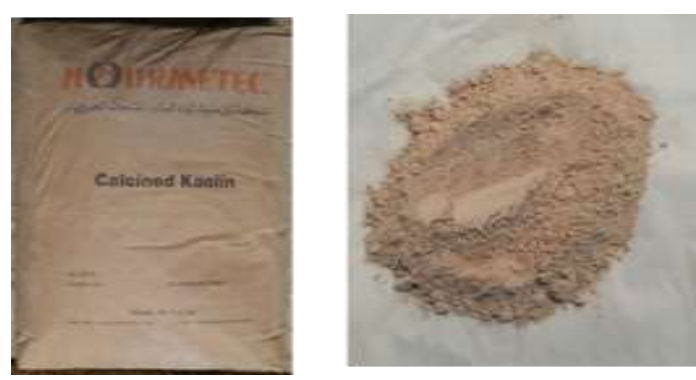

Figure 2. Calcined Kaolin (Metakolin)

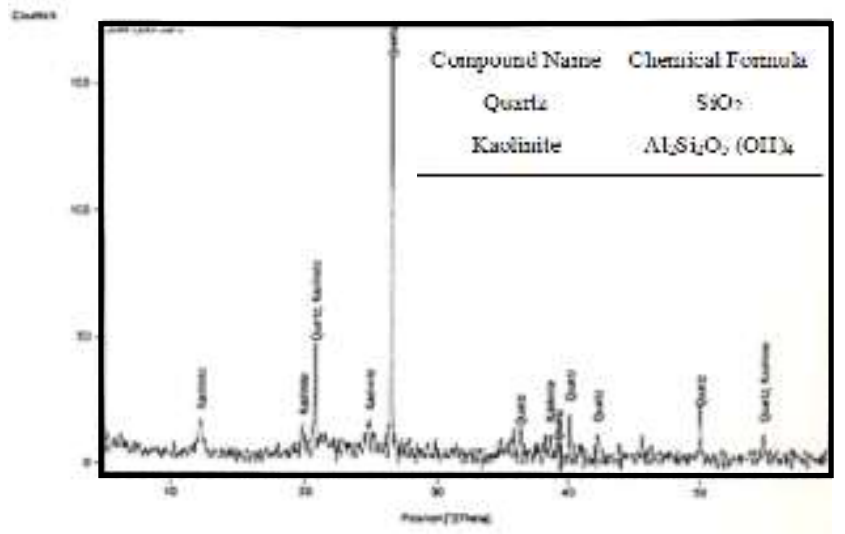

Figure 3. X-ray diffraction of Metakaolin

TABLE I. THE CHEMICAL COMPONENTS ANALYSIS RESUlt OF THE USED METAKAOLIN

\begin{tabular}{|c|c|}
\hline $\begin{array}{c}\text { Chemical } \\
\text { Composition }\end{array}$ & Average (\%) \\
\hline $\mathrm{SiO}_{2}$ & 53.90 \\
\hline $\mathrm{Al}_{2} \mathrm{O}_{3}$ & 35.90 \\
\hline $\mathrm{Fe}_{2} \mathrm{O}_{3}$ & 1.57 \\
\hline $\mathrm{CaO}$ & 0.95 \\
\hline $\mathrm{MgO}$ & 0.17 \\
\hline $\mathrm{Na}_{2} \mathrm{O}+\mathrm{K}_{2} \mathrm{O}$ & 0.16 \\
\hline $\mathrm{L} . \mathrm{O} . \mathrm{I}$ & 3.95 \\
\hline
\end{tabular}

\section{B. Mixtures Proportions}

Seven contents of Metakaolin were used as a percentage from $0.0 \%$ to $30 \%$ as adding and replacement of the mixture cement content $(\mathrm{MK} / \mathrm{C})$ to investigate its effect on the selfcompacting concrete. Super-plasticizer is used as $1.0 \%$ percentage by weight of binder content. Cement content was chosen as 450, 550 and $650 \mathrm{~kg} / \mathrm{m}^{3}$. Sand and crushed dolomite content was the same for all the mixtures in this research.

\section{Concrete Samples}

Specimens in this research cast to explore the main properties of the different 39 concrete mixes, which are the compressive strength and the indirect tensile strength. Standard cubes of dimensions 100x100x100 mm were used to measure the compressive strength and cylinders of $100 \mathrm{~mm}$ diameter and $200 \mathrm{~mm}$ height were used to measure the indirect tensile strength. 
Proc. of the Fourth International Conference on Advances in Civil, Structural and Environmental Engineering - ACSEE 2016.

Copyright (C) Institute of Research Engineers and Doctors. All rights reserved.

ISBN: 978-1-63248-114-6 doi: 10.15224/ 978-1-63248-114-6-25

\section{Testing Procedures and Equipment}

\section{1) Fresh (SCC)}

Fresh concrete tests are necessary in this study. SCC is defined by its behaviour when it is in the fresh state, and it is determined whether concrete meets certain requirements. The workability tests which are mainly recommended by the British standards (BS EN 206-9, 2010) are the slump flow test for flowing ability and J-ring tests for passing ability. In this section, new developed test (MSF apparatus) was described.

\section{A) MSF Apparatus Test}

MSF Apparatus test is the chosen name for the new test procedure and the dimension of the used apparatus is shown in Fig. 4, the MSF Apparatus test is used to appraise the deformability of SCC in the absence of obstacles. This test gives rapid indication about two different aspects; the filling ability and the segregation resistance in this test can be detected visually. The main advantages of the MSF Apparatus test is that it need small volume of fresh concrete about (1.0 litre) and the required space for the test is also small (need a plate of $(400 \times 400 \mathrm{~mm})$ compared to that of the ordinary slump flow test that need (about 9.0 Litters).
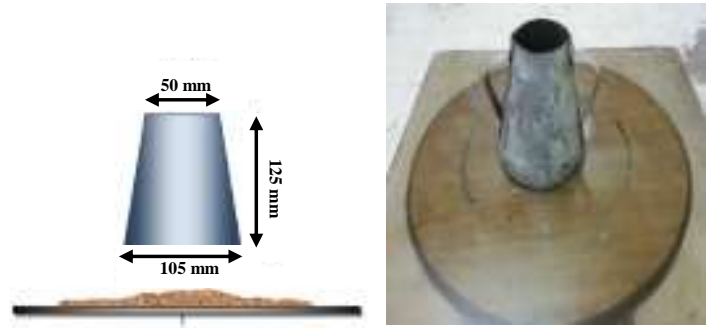

Figure 4. MSF Apparatus test cone dimensions

\section{- Test Apparatus}

- Mould: Steel cone mould with diameters of $50 \mathrm{~mm}$ at bottom and $105 \mathrm{~mm}$ at top with $125 \mathrm{~mm}$ height.

- Base Plate: non-absorbent, smooth, and rigid and have dimensions of $400 \times 400 \mathrm{~mm}$ with plotted circle of $200 \mathrm{~mm}$ diameter in the centre.

\section{- $\quad$ Test Procedure and Calculations}

The procedure and calculations of MSF Apparatus test is the same as slump flow test which is recommended by the British standard (BS EN 206-9, 2010) except that the measured time needed for SCC to reach $500 \mathrm{~mm}$ diameter is replaced by that measured to reach $200 \mathrm{~mm}$ flow $\left(\mathrm{T}_{200}\right)$.

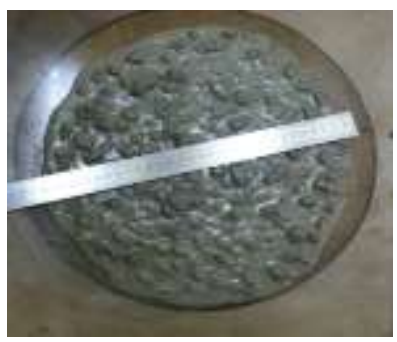

(5-a) Good flow-ability (Accepted sample)

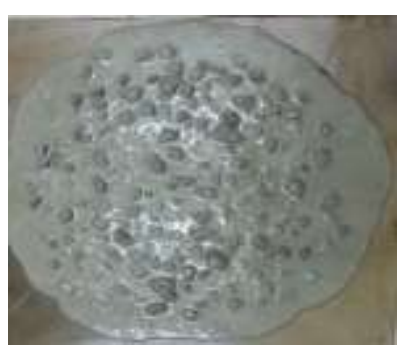

(b-1) Segregation

\section{- Acceptance Limits}

- Achieving a large diameter with no segregation indicates a good deformability.

- T200 'the time needed for SCC to reach a diameter of $200 \mathrm{~mm}$ ' should be between 5 to 10 seconds.

- The average slump flow diameter should be between 250 to $280 \mathrm{~mm}$.

- $\quad$ Segregation can be detected by visually inspecting a ring of cement paste/mortar in the edge of flow, and /or ensuring that no coarse aggregates has lifted in the centre of flow.

- This limits are valid for aggregates with maximum nominal size not more than $12.50 \mathrm{~mm}$.

\section{2) Hardened (SCC)}

The hardened concrete tests which are recommended by Egyptian Standard Specification (E.S.S. 4756-1/2009) are compression test and indirect tension test. Compression test was carried out to determine the compressive strength of specimens of concrete cubes. Indirect tension test (splitting method) was performed to determine the tensile strength of concrete mixes using cylindrical specimens.

\section{Iv. Test Results and Discussions}

The test results of fresh and hardened concrete are analysed to investigate the effect of different contents of cement as well as the effect of adding and replacing Metakaolin contents on the self-compacted concrete. The results of the performed experimental work are divided in two phases.

\section{A. Phase One:}

In this phase different cement and Metakaolin (MK) contents with different water to binder ratios (W/B) and $1.0 \%$ super-plasticizer content were tested using MSF Apparatus test to determine the acceptable water to binder ratios that meet the requirements of the self-compacted concrete.

Thirty nine mixes were chosen as an acceptable mixes that satisfied the requirements of self-compacted concrete and with minimum water to binder ratio. Table 2 show the selected mixes, MSF Apparatus test results and comparable slump flow d J-Ring test results. Fig. 5(a) shows an accepted sample, while Fig. 5(b) shows refused samples using MSF Apparatus test.

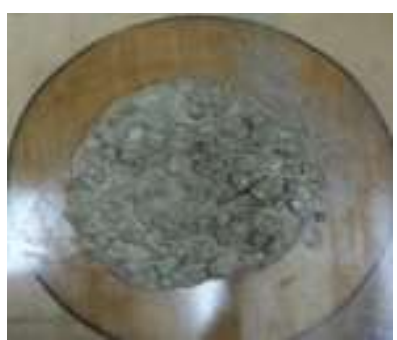

(b-2) Low Flow-ability (5-b) Refused samples

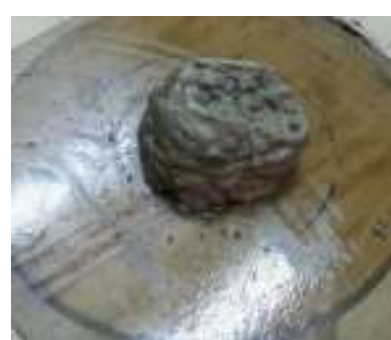

(b-3) Unflowable

Figure 5. MSF Apparatus test accepted and refused sample 
Proc. of the Fourth International Conference on Advances in Civil, Structural and Environmental Engineering - ACSEE 2016. Copyright (C) Institute of Research Engineers and Doctors. All rights reserved.

ISBN: 978-1-63248-114-6 doi: 10.15224/ 978-1-63248-114-6-25

TABLE II. FRESH AND HARDNED CONCRETE TEST RESULTS

\begin{tabular}{|c|c|c|c|c|c|c|c|c|c|c|c|c|c|}
\hline \multirow{2}{*}{$\begin{array}{l}\text { Mix } \\
\text { No. }\end{array}$} & \multirow{2}{*}{$\begin{array}{c}\mathrm{C} \\
\left(\mathrm{Kg} / \mathrm{m}^{3}\right)\end{array}$} & \multirow{2}{*}{$\begin{array}{l}\mathrm{W} / \mathrm{B} \\
(\%)\end{array}$} & \multirow{2}{*}{$\begin{array}{c}(\mathrm{MK} / \mathrm{C}) \\
(\%)\end{array}$} & \multicolumn{2}{|c|}{$\begin{array}{c}\text { MSF } \\
\text { Apparatus test }\end{array}$} & \multicolumn{2}{|c|}{$\begin{array}{l}\text { Slump flow } \\
\text { test }\end{array}$} & \multicolumn{2}{|c|}{ J-Ring test } & \multicolumn{2}{|c|}{$\begin{array}{c}\text { Compressive strength } \\
\text { (MPa) }\end{array}$} & \multicolumn{2}{|c|}{$\begin{array}{l}\text { Tensile strength } \\
\text { (MPa) }\end{array}$} \\
\hline & & & & $\begin{array}{l}\text { Time } \\
\text { (Sec.) }\end{array}$ & $\begin{array}{l}D_{\text {ave }} \\
(\mathrm{Cm}) \\
\end{array}$ & $\begin{array}{l}\text { Time } \\
(\text { Sec.) }\end{array}$ & $\begin{array}{l}\mathrm{D}_{\text {ave }} \\
(\mathrm{Cm})\end{array}$ & $\begin{array}{l}\text { Time } \\
(\text { Sec.) } \\
\end{array}$ & $\begin{array}{l}\text { Dave } \\
(\mathrm{Cm})\end{array}$ & 7 days & 28 days & 7 days & 28 days \\
\hline M1 & \multirow{13}{*}{450} & 0.39 & 0 & 9.5 & 26 & 4.5 & 70 & 4.95 & 69 & 38.43 & 44.79 & 3.65 & 4.22 \\
\hline M2 & & 0.38 & 5 & 7.62 & 27 & 3.98 & 73 & 4.23 & 72.5 & 39.17 & 45.91 & 3.88 & 4.61 \\
\hline M3 & & 0.38 & 10 & 7.41 & 26.5 & 4.02 & 74 & 4.65 & 73.5 & 42.41 & 47.02 & 4.04 & 5.16 \\
\hline M4 & & 0.38 & 15 & 7.2 & 26.5 & 4.08 & 73.5 & 4.22 & 72 & 43.85 & 48.74 & 4.36 & 5.49 \\
\hline M5 & & 0.38 & 20 & 8.21 & 26.5 & 4.44 & 68 & 4.76 & 66 & 41.92 & 47.79 & 3.96 & 5.11 \\
\hline M6 & & 0.38 & 25 & 8.9 & 25 & 4.75 & 69 & 5.01 & 67.5 & 39.99 & 43.99 & 3.61 & 4.34 \\
\hline M7 & & 0.38 & 30 & 7.81 & 26.5 & 3.51 & 75 & 4.12 & 73.5 & 32.00 & 35.20 & 3.12 & 3.83 \\
\hline M8 & & 0.39 & -5 & 9.1 & 26.5 & 4.45 & 72 & 4.97 & 70.5 & 34.02 & 37.52 & 3.54 & 3.98 \\
\hline M9 & & 0.43 & -10 & 7.56 & 27.5 & 4.73 & 73 & 5.08 & 71 & 36.48 & 39.41 & 3.66 & 4.18 \\
\hline M10 & & 0.43 & -15 & 7.41 & 27.5 & 4.42 & 74 & 4.95 & 72.5 & 41.35 & 46.32 & 3.88 & 4.43 \\
\hline M11 & & 0.43 & -20 & 7.82 & 26.5 & 3.24 & 75 & 3.97 & 74 & 33.17 & 37.79 & 2.85 & 3.36 \\
\hline M12 & & 0.43 & -25 & 9.12 & 25.5 & 4.63 & 71 & 4.87 & 69.5 & 25.47 & 31.51 & 2.65 & 3.27 \\
\hline M13 & & 0.43 & -30 & 6.64 & 25.5 & 4.23 & 70.5 & 4.93 & 69 & 23.11 & 30.26 & 2.55 & 3.19 \\
\hline M14 & \multirow{13}{*}{550} & 0.33 & 0 & 8.25 & 28 & 3.14 & 74 & 3.98 & 73 & 47.62 & 51.28 & 5.09 & 6.25 \\
\hline M15 & & 0.33 & 5 & 7.53 & 26.75 & 4.66 & 69 & 4.74 & 67.5 & 51.77 & 59.61 & 5.87 & 7.01 \\
\hline M16 & & 0.32 & 10 & 7.54 & 26.25 & 4.51 & 70 & 4.96 & 68.5 & 56.93 & 67.94 & 6.21 & 7.77 \\
\hline M17 & & 0.32 & 15 & 7.24 & 27.5 & 4.63 & 69 & 5.02 & 67.5 & 58.86 & 73.74 & 7.01 & 8.10 \\
\hline M18 & & 0.32 & 20 & 9.78 & 27 & 4.21 & 67 & 4.81 & 66.5 & 54.17 & 62.58 & 6.48 & 7.45 \\
\hline M19 & & 0.32 & 25 & 7.67 & 26 & 4.12 & 71 & 3.97 & 69 & 50.86 & 59.45 & 5.72 & 6.91 \\
\hline M20 & & 0.33 & 30 & 6.67 & 26.5 & 4.35 & 69 & 4.93 & 67 & 40.77 & 48.12 & 5.10 & 6.42 \\
\hline M21 & & 0.33 & -5 & 6.9 & 26 & 4.47 & 68.5 & 5.01 & 67 & 44.15 & 49.29 & 4.96 & 6.70 \\
\hline M22 & & 0.36 & -10 & 6.2 & 25.75 & 4.20 & 67.5 & 4.64 & 66 & 45.71 & 50.46 & 5.04 & 6.95 \\
\hline M23 & & 0.36 & -15 & 5.9 & 26.25 & 3.75 & 72.5 & 4.25 & 73 & 49.13 & 54.20 & 5.22 & 7.07 \\
\hline M24 & & 0.36 & -20 & 6.3 & 25.5 & 4.52 & 69.5 & 4.90 & 69 & 40.58 & 47.50 & 4.59 & 6.48 \\
\hline M25 & & 0.36 & -25 & 7.31 & 26.75 & 3.98 & 71.5 & 4.20 & 70 & 37.75 & 42.44 & 4.00 & 5.90 \\
\hline M26 & & 0.36 & -30 & 7.86 & 25 & 3.86 & 69.5 & 4.68 & 68.5 & 36.15 & 40.97 & 3.84 & 5.45 \\
\hline M27 & \multirow{13}{*}{650} & 0.3 & 0 & 6.57 & 25.5 & 4.45 & 70 & 5.3 & 71 & 50.00 & 58.80 & 5.86 & 6.56 \\
\hline M28 & & 0.3 & 5 & 5.89 & 27.5 & 4.61 & 70 & 4.93 & 68.5 & 52.85 & 67.13 & 6.23 & 7.24 \\
\hline M29 & & 0.29 & 10 & 8.65 & 26.5 & 4.50 & 71 & 4.89 & 70 & 58.78 & 74.47 & 6.70 & 8.02 \\
\hline M30 & & 0.29 & 15 & 9.65 & 26.5 & 4.80 & 72 & 5.1 & 70 & 61.95 & 78.15 & 7.48 & 8.36 \\
\hline M31 & & 0.29 & 20 & 6.97 & 25.75 & 4.12 & 70.5 & 4.25 & 69 & 60.38 & 68.64 & 6.76 & 7.56 \\
\hline M32 & & 0.29 & 25 & 6.35 & 27.5 & 4.87 & 69 & 5.04 & 68 & 55.96 & 65.20 & 6.21 & 7.15 \\
\hline M33 & & 0.29 & 30 & 8.32 & 27 & 4.53 & 71 & 4.80 & 69.5 & 51.25 & 55.27 & 5.83 & 6.82 \\
\hline M34 & & 0.3 & -5 & 5.64 & 27 & 4.70 & 71 & 4.93 & 70 & 46.30 & 57.93 & 5.68 & 6.91 \\
\hline M35 & & 0.33 & -10 & 7.51 & 26.5 & 4.21 & 70 & 4.5 & 68.5 & 47.25 & 58.15 & 5.86 & 7.22 \\
\hline M36 & & 0.33 & -15 & 7.63 & 27.5 & 4.57 & 69 & 4.69 & 68 & 51.42 & 62.05 & 6.05 & 7.50 \\
\hline M37 & & 0.33 & -20 & 6.53 & 25.5 & 4.24 & 71 & 4.93 & 68.5 & 43.75 & 54.51 & 5.43 & 6.69 \\
\hline M38 & & 0.33 & -25 & 7.31 & 26 & 4.88 & 70.5 & 5.20 & 69 & 39.29 & 49.12 & 4.57 & 6.34 \\
\hline M39 & & 0.33 & -30 & 6.39 & 27.5 & 4.75 & 71 & 4.91 & 70 & 38.50 & 46.14 & 4.22 & 6.13 \\
\hline
\end{tabular}

*Fine aggregate and coarse aggregate contents were fixed to $762 \mathrm{~kg} / \mathrm{m}^{3}$, while super-plasticizer content was chosen as $1.0 \%$ of binder content

\section{B. Phase Two:}

The hardened properties of the self-compacted concrete which were taken into consideration in phase two in this research were the compressive strength at age of 7 and 28 days and the indirect tensile strength at age of 7 and 28 days of the self-compacted concrete. In the second phase fresh and hardened properties of self-compacted concrete were investigated and the tests results are presented and discussed.

\section{1) Mechanical Properties Results and Discussion:}

The compressive strength test results are shown in Table 2 and Figs. 6 to 9 and the indirect tensile strength test results are shown in Table 2 and Figs. 10 to 13. The results show that there is a great positive effect of increasing Metakaolin content on both the compressive and the tensile strength of SCC at 7 and 28 days regardless cement content. 
Proc. of the Fourth International Conference on Advances in Civil, Structural and Environmental Engineering - ACSEE 2016. Copyright (C) Institute of Research Engineers and Doctors. All rights reserved. ISBN: 978-1-63248-114-6 doi: 10.15224/ 978-1-63248-114-6-25

By adding MK/C of 5 to 30 percentage, it was observed that increasing Metakaolin content affect the compressive strength and tensile strength which tended to increase and then decreased. At the age of 7 days and 28 days the maximum increase was at $15 \% \mathrm{MK} / \mathrm{C}$ percentage.

At the age of 7 days, the compressive strength increased by about $14.12 \%, 23.60 \%$ and $23.90 \%$ at 450,550 and $650 \mathrm{Kg} / \mathrm{m}^{3}$ cement contents respectively while the tensile strength increased by about $19.45 \%, 37.72 \%$ and $27.65 \%$ at 450,550 and $650 \mathrm{Kg} / \mathrm{m}^{3}$ cement contents respectively with adding (MK/C\%) compared to samples without MK. At the age of 28 days, the compressive strength increased by about $8.82 \%, 43.80 \%$ and $32.90 \%$ at 450,550 and $650 \mathrm{Kg} / \mathrm{m}^{3}$ cement contents respectively while the tensile strength increased by about $30.09 \%, 29.60 \%$ and $27.44 \%$ at 450,550 and $650 \mathrm{Kg} / \mathrm{m}^{3}$ cement contents respectively with adding Metakaolin to cement percentages (MK/C\%) compared to samples without MK.

Using MK as a replacement by weight of cement of 5 to 30 percentages, the compressive strength and the tensile strength first decreased and then increased. At the age of 7 days and 28 days the maximum increase was at $15 \% \mathrm{MK} / \mathrm{C}$ percentage. The compressive strength increased by about $7.61 \%, 3.17 \%$ and $2.83 \%$ at 450,550 and $650 \mathrm{Kg} / \mathrm{m}^{3}$ cement contents respectively at the age of 7 days while the maximum tensile strength increase was about $6.30 \%, 2.55 \%$ and $3.24 \%$ at 450,550 and $650 \mathrm{Kg} / \mathrm{m}^{3}$ cement contents respectively. At the age of 28 days, the compressive strength increased by about $3.41 \%, 5.70 \%$ and $5.53 \%$ at 450,550 and $650 \mathrm{Kg} / \mathrm{m}^{3}$ cement contents respectively compared to samples without MK. The maximum tensile strength increase was at $15 \% \mathrm{MK} / \mathrm{C}$ percentage. The tensile strength was increased by about $4.98 \%, 13.12 \%$ and $14.33 \%$ at 450 , 550 and $650 \mathrm{Kg} / \mathrm{m}^{3}$ cement contents respectively compared to samples without $\mathrm{MK}$ with respect to samples with replacing $(\mathrm{MK} / \mathrm{C} \%)$.

Increasing the cement content increases the compressive strength and also the tensile strength of SCC samples' at age of 7 and 28 days. For samples with adding MK/C percentage the compressive strength at 7 days increased with average of $29.80 \%$ at $550 \mathrm{Kg} / \mathrm{m}^{3}$ and by about $41.30 \%$ at $650 \mathrm{Kg} / \mathrm{m}^{3}$ cement content. The tensile strength at 7 days increased with average of $55.90 \%$ at $550 \mathrm{Kg} / \mathrm{m}^{3}$ and by about $69.80 \%$ at $650 \mathrm{Kg} / \mathrm{m}^{3}$ cement content compared to cement content of $450 \mathrm{~kg} / \mathrm{m}^{3}$. At 28 days the compressive strength increased with the increasing of cement content by with average of $34.70 \%$ at $550 \mathrm{Kg} / \mathrm{m}^{3}$ and by about $49.30 \%$ at $650 \mathrm{Kg} / \mathrm{m}^{3}$ cement content, while the tensile strength increased with the increasing of cement content by about $53.0 \%$ at $550 \mathrm{Kg} / \mathrm{m}^{3}$ and by about $58.80 \%$ at $650 \mathrm{Kg} / \mathrm{m}^{3}$ cement content compared to cement content of $450 \mathrm{~kg} / \mathrm{m}^{3}$.

For samples with replacing $\mathrm{MK} / \mathrm{C}$ percentage the compressive strength at 7 days increased with average of $33.50 \%$ at $550 \mathrm{Kg} / \mathrm{m}^{3}$ and by about $40.45 \%$ at $650 \mathrm{Kg} / \mathrm{m}^{3}$ cement content. The tensile strength at 7 days increased by about $45.80 \%$ at $550 \mathrm{Kg} / \mathrm{m}^{3}$ and by about $67.50 \%$ at $650 \mathrm{Kg} / \mathrm{m}^{3}$ cement content compared to cement content of $450 \mathrm{~kg} / \mathrm{m}^{3}$. At 28 days the compressive strength increased with the increasing of cement content by about $28.70 \%$ at $550 \mathrm{Kg} / \mathrm{m}^{3}$ and by about $48.10 \%$ at $650 \mathrm{Kg} / \mathrm{m}^{3}$ cement content. While the tensile strength increased with the increasing of cement content by about $73.10 \%$ at $550 \mathrm{Kg} / \mathrm{m}^{3}$ and by about $83.50 \%$ at $650 \mathrm{Kg} / \mathrm{m}^{3}$ cement content compared to cement content of $450 \mathrm{~kg} / \mathrm{m}^{3}$.

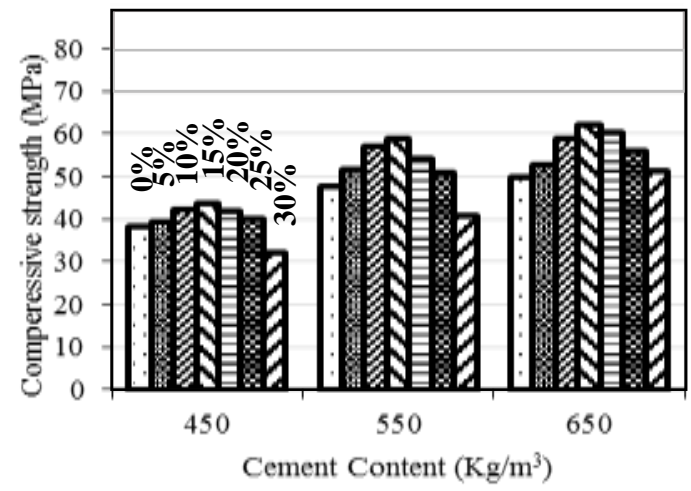

Figure 6. Effect of Cement content with adding Metakaolin contents (MK\%) on 7 days compressive strength

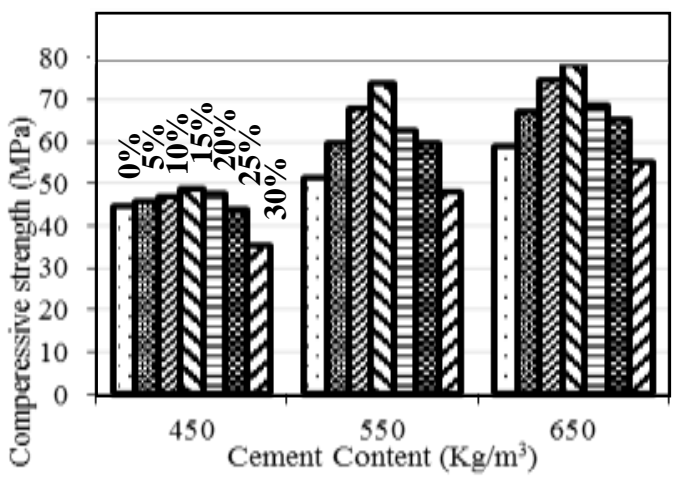

Figure 7. Effect of Cement content with adding Metakaolin contents (MK\%) on 28 days compressive strength

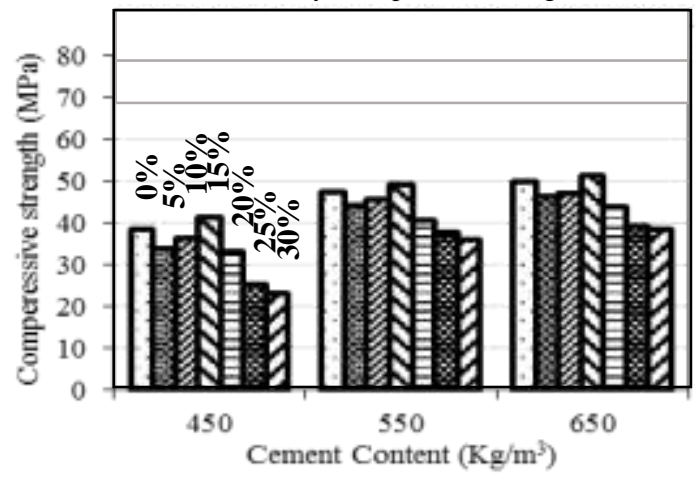

Figure 8. Effect of Cement content with replacing Metakaolin contents

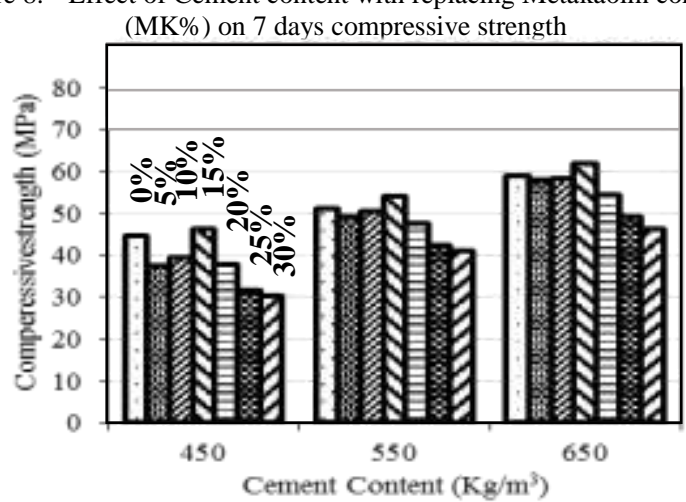

Figure 9. Effect of Cement content with replacing Metakaolin contents (MK\%) on 28 days compressive strength 
Proc. of the Fourth International Conference on Advances in Civil, Structural and Environmental Engineering - ACSEE 2016. Copyright (C) Institute of Research Engineers and Doctors. All rights reserved. ISBN: 978-1-63248-114-6 doi: 10.15224/ 978-1-63248-114-6-25

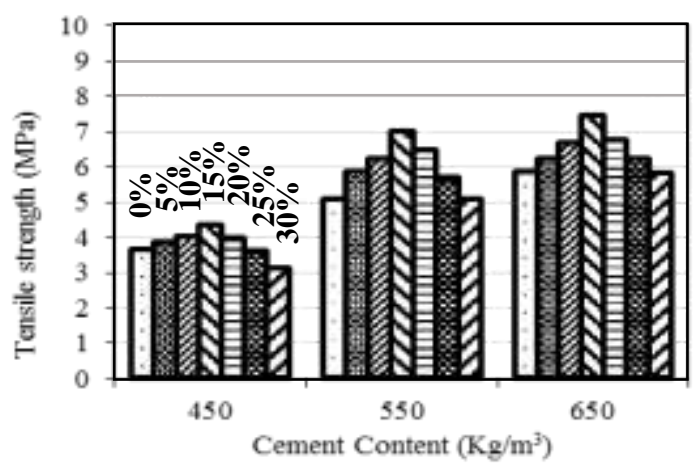

Figure 10. Effect of Cement content with adding Metakaolin contents (MK\%) on 7 days tensile strength

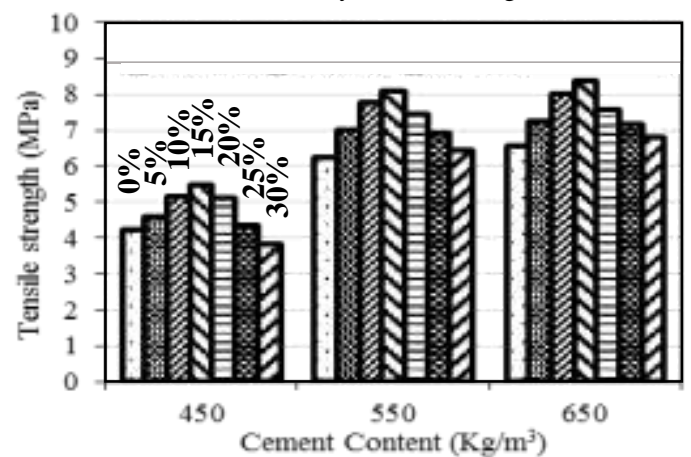

Figure 11. Effect of Cement content with adding Metakaolin contents $(\mathrm{MK} \%)$ on 28 days tensile strength

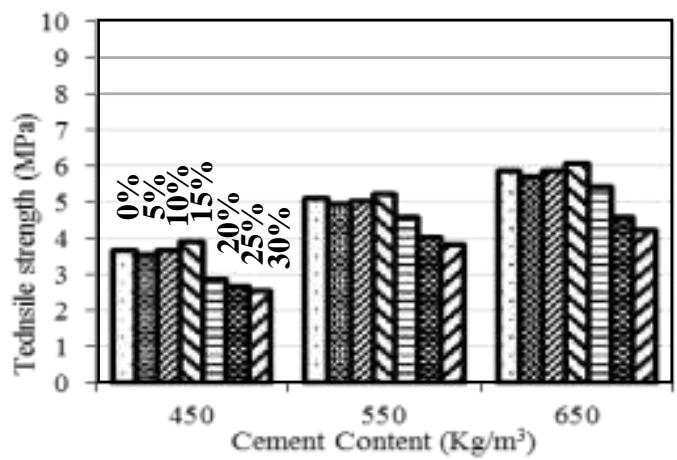

Figure 12. Effect of Cement content with replacing Metakaolin contents (MK\%) on 7 days tensile strength

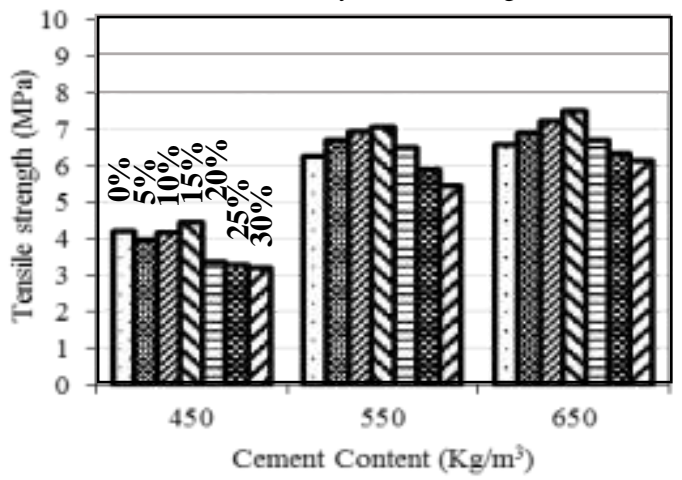

Figure 13. Effect of Cement content with replacing Metakaolin contents (MK\%) on 28 days tensile strength

From the previous results it could be indicated that that adding or replacing $15 \%$ Metakaolin to cement percentage was the best percentage in the 7 and 28 days compressive and tensile strength which were coincident with the results of (Rawat, 2012; Sabir et al., 2001).

\section{v. Conclusions}

Based on the results obtained from the current research, the following main conclusions can be summarized:

- Self-compacted concrete can be achieved using Metakaolin as a cementitous material.

- The MSF Apparatus test is a new developed test that need small volume of fresh concrete about (1.0 litre) and required small space for the test compared to that of the ordinary slump flow test that need.

- The MSF Apparatus test results is highly accurate comparing with indicated results from the slump flow test and J-Ring test.

- There is a great positive effect of increasing Metakaolin content on the compressive and tensile strength at 7 and 28 days age for self-compacted concrete.

- Using Metakaolin content from 5 to $15 \%$ by weight of cement as adding or replacement gives higher strength than samples without Metakaolin content. The maximum strength could be obtained by using $15 \%$ of Metakaolin as adding or replacing percentage by weight of cement.

- The increasing in cement content has a positive effect on the compressive strength and tensile strength at 7 and 28 days of self-compacted concrete ages without considering the Metakaolin content.

\section{References}

[1] ASTM C 494-03, (2003). American Society for Testing and Materials: Chemical Admixtures, Philadelphia, USA.

[2] BS EN 206-9:2010, (2010). "Additional rules for self-compacting concrete (SCC)". British Adopted European Standard.

[3] Christianto H. (2004). "Effect of Chemical and Mineral Admixtures on The Fresh Properties of Self-Compacting Mortars." M.Sc. Thesis, Civil Engineering, Middle East Technical University, Ankara, Turkey.

[4] E.S.S. 4756-1/2009, (2009). Egyptian Standard Specification for Ordinary Portland Cement, Egypt.

[5] NRMCA (2000). "Supplementary Cementitious Materials." National Ready Mixed Concrete Association http://www.nrmca.org/aboutconcrete/cips/30p.pdf.

[6] Rashid M. and M.M. (2009). "Considerations in producing high strength concrete." Journal of Civil Engineering (IEB), Vol. 37 (1), pp. 53-63. http://www.jce-ieb.org/pdfdown/3701005.pdf.

[7] Rawat I.P. (2012). "Mechanical Properties and Sulphate Resistance of Concrete, Incorporating used Foundry Sand, Silica Fume and Metakaolin.” M.Sc. in Civil Engineering (Structures), Department of Civil Engineering, Thapar University, Patiala, India.

[8] Sabir B.B., S. W. and Bai J. (2001). "Metakaolin And Calcined Clays as Pozzolans for Concrete: a review." Cement and Concrete Composites, Vol. 23, No. 6, pp. 441-454, DOI: 10.1016/S09589465(00)00092-5.

[9] Sanjay N. P., K. G. and Subhash S. (2013). "Metakaolin Pozzolanic Material for Cement in High Strength Concrete." in Proceedings of the 2nd International Conference on Emerging Trends in Engineering (SICETE '13), pp. 46-49.

[10] Shekarchi, A. B., Bakshi, A. M. and Mobasher (2010). "Transportation Properties in Metakaolin Blended Concrete." Construction and Building Materials, Vol. 24, No. 11, pp. 2217-2223, DOI: 10.1016/j.conbuildmat.2010.04.035.

[11] Yusuff A. (2005). "Behaviour of High Strength Reinforced Concrete Beam With Metakaolin Under Static Loading." M.Sc., Civil Engineering Department, University Technology, Malaysia. 